\title{
Особливості когнітивних функцій у квалісікованих бадмінтоністів
}

\author{
Сюй Саньцянь ${ }^{1}$, Георгій Коробейніков \\ Діана Міщук², Леся Коробейнікова ${ }^{1}$
}

${ }^{1}$ Національний університет фрізичного виховання і спорту України, Київ, Україна 2 Національний технічний університет України «КПІ імені Ігоря Сікорського», Київ, Україна

Анотація. Сучасний спортсмен, який грає у бадмінтон на високому спортивному рівні, повинен бути дуже добре підготовлений фрізично, досконало володіти різними технічними прийомами, мати широкий арсенал тактичних рішень та демонструвати високий рівень стресостійкості. Фахівці вказують, що оцінювання спортсменів за психофізіологічними якостями більш прогнозоване, ніж визначення рівня розвитку фізичних якостей, тому що психофрізіологічні якості генетично більш консервативні і менш динамічні в онтогенезі, ніж фізичні. Когнітивні здібності розглядаються як індивідуальні стійкі особливості, що визначають своєрідність стратегії сприйняття і переробки інформації, вирішення завдань, навчання і інших видів пізнавальної діяльності. Актуальним $€$ те, що ефективність бадмінтоністів високої кваліфікації залежить від здатності до сприйняття, аналізу і переробки інформації. Вивчення психофрізіологічних функцій з метою контролю над функціональним станом спортсмена і корекцією тренувального процесу є дуже важливим. Мета. Визначити рівень когнітивних фрункцій у кваліфікованих бадмінтоністів. Методи. Дослідження проводилися 3 використанням апаратно-програмного комп'ютерного комплексу «Мультипсихометр-05». Для вивчення когнітивних функцій кваліфрікованих бадмінтоністів були обрані просунуті прогресивні матриці Равена. У дослідженнях було застосовано першу частину тесту, що являє собою експрес-варіант, складається 312 завдань та охоплює весь діапазон здібностей, діагностованих повним тестом. Результати. За основним інформативним показником (продуктивністю), швидкістю та точністю бадмінтоністи високої кваліфікації мають середній рівень, за показником ефективності - нижчий за середній. Аналіз тесту «Прогресивні матриці Равена» показав, що жінки мають достовірно кращі значення за основним інформативним показником продуктивності, якості (точності) та ефективності виконання тестування когнітивних здібностей.

Ключові слова: когнітивні функції, бадмінтоністи високої кваліфікації, рівень загальних когнітивних здібностей.

\section{Xu Sanqian, Heorhii KorobeynikovB, Diana Mishchuk, Lesia Korobeynikova}

\section{FEATURES OF COGNITIVE FUNCTIONS IN QUALIFIED BADMINTON PLAYERS}

Abstract. A modern athlete who plays badminton at a high level must be very well prepared physically, have a good command of various technical skills, have a wide arsenal of tactical solutions and demonstrate a high level of stress resistance. Experts point out that the assessment of athletes by psychophysiological qualities is more predictable than determining the level of physical capacity development, because psychophysiological qualities are genetically more conservative and less dynamic in ontogenesis than physical ones. Cognitive abilities are considered as individual stable features that determine the uniqueness of the strategy of information perception and processing, problem solving, learning and other types of cognitive activity. It is important that the effectiveness of highly qualified badminton players depends on the ability to perceive, analyze and process information. The study of psychophysiological functions to control the athlete functional state and to correct the training process is very important. Objective. Determine the level of cognitive functions in qualified badminton players. Methods. The research was conducted using the hardware-software computer complex «Multipsychometer-05».

Xu Sanqian, Korobeynikov H., Mishchuk D. Korobeynikova L. Features of cognitive functions in qualified badminton players. Theory and Methods of Physical education and sports. 2021; 1: 9-12 DOI: 10.32652/tmfvs.2021.1.9-12
Сюй Саньцянь, Коробейніков Г., Міщук Д., Коробейнікова Л. Особливості когнітивних функцій у кваліфрікованих бадмінтоністів. Теорія і методика фрізичного виховання і спорту. 2021; 1: 9-12

DOI: 10.32652/tmfvs.2021.1.9-12
Вступ. Бадмінтон користується великим попитом серед населення та завоював популярність через свою демократичність. У цю гру можуть грати усі, незалежно від статі та віky [2, 3].

На початковому рівні спортсменам доступні найпростіші елементи гри, які не вимагають багатого технічного арсеналу. На більш високому рівні бадмінтон значно динамічніший і вимагає від гравців високого рівня атлетичної підготовки [3, 4]. Сучасний спортсмен, що грає у бадмінтон на високому спортивному рівні, повинен бути дуже добре підготовлений фізично, досконало володіти різними технічними прийомами, мати широкий арсенал тактичних рішень та демонструвати високий рівень стресостійкості [5-7].

За своїми характеристиками бадмінтон належить до ациклічних складно-координаційних видів спорту, для нього характерні такі особливості: швидкість рухів; швидкість мислення; швидкість виконання технічних прийомів.

Високі результати в спорті вищих досягнень демонструють спортсмени, які мають комплекс видатних особливостей:

- хороші рухові якості (швидкісні і швидкісно-силові, координаційні здібності в усіх проявах, гнучкість та витривалість);

- високі психофрізіологічні характеристики: оперативне мислення, всі види реакцій (проста зорово-моторна, реакція вибору, реакція на рухомий предмет), швидкість переробки інформації, прийняття рішення, різні прояви уваги (розподіл, переключення, інтенсивність, стійкість, зосередженість);

- психічні (особисті) риси характеру: цілеспрямованість, рішучість, завзятість, сміливість, наполегливість, витримка, самостійність, ініціативність, терпіння, надійність, честолюбство, ініціатива, скромність, чесність, бойовий дух, щирість. 
Advanced progressive Raven matrices were applied to study the cognitive functions of skilled badminton players. The research used the first part of the test, which is an express version, consists of 12 tasks and covers the full range of abilities diagnosed by the full test. Results. According to the main informative index (productivity), speed and accuracy, highly qualified badminton players have an average level, whereas according to the efficiency index -below average. The analysis of the "Raven's Progressive Matrices" test showed that women have significantly better values in terms of the main informative index of productivity, quality (accuracy) and effectiveness of cognitive abilities testing.

Keywords: cognitive functions, highly qualified female badminton players, level of general cognitive abilities.

Зважаючи на те що ефрективність бадмінтоністів високої кваліфікації залежить від здатності спортсмена до сприйняття, аналізу і переробки інформації, вивчення психофрізіологічних фуннкцій з метою контролю над функціональним станом спортсмена і корекцією тренувального процесу $є$ дуже важливим [1, 8, 9].

Фахівці вказують, що оцінювання спортсменів за психосрізіологічними якостями більш прогнозоване, ніж визначення рівня розвитку фізичних якостей, тому що психофрізіологічні якості генетично більш консервативні і менш динамічні в онтогенезі, ніж фрізичні [3-5].

В. Помиткін вказує, що аналіз опитування провідних тренерів та спортсменів виявив помітну переважаючу роль ігрових і психофізіологічних особливостей бадмінтоністів [1].

Когнітивні здібності розглядаються як індивідуальні стійкі особливості, які визначають своєрідність стратегії сприйняття і переробки інформації, вирішення завдань, навчання й інших видів пізнавальної діяльності $[3,6,8]$.

Усі пізнавальні здібності людини, об'єднані загальною здатністю до пізнання і вирішення труднощів, залежать від рівня загальних когнітивних здібностей. Розвиток певних інтелектуальних здібностей залежить від змісту діяльності людини, визначається не тільки генотипом індивіда, а й багатством його життєвого досвіду. Численні критерії елементів фуннцціональної системи, які впливають на результат діяльності, обумовлюють психофрізіологічні механізми когнітивної діяльності людини. Тому важливим $є$ оцінювання способів сприйняття і пе- реробки інфрормації на рівні прийняття рішень.

Мета дослідження - визначити рівень когнітивних функцій у кваліфікованих бадмінтоністів.

Методи дослідження. використання апаратно-програмного комп'ютерного комплексу «Мультипсихо метр-05». Для вивчення когнітивних функцій кваліфікованих бадмінтоністів було обрано прогресивні матриці Равена [2]. Застосовано першу частину тесту, що являє собою експрес-варіант тесту, складається з 12 завдань та охоплює весь діапазон здібностей, діагностованих повним тестом (використовується для швидкого розподілу іспитованих за рівнем інтелекту).

Результати дослідження та їх обговорення. Усі завдання було розташовано в порядку зростання складності. Іспитований повинен обрати правильну відповідь з восьми запропонованих варіантів, на виконання тесту відведено 6 хв.

За допомогою тесту визначають показники рівня інтелекту:

- продуктивність (основний інфрормативний показник) - загальна кількість правильно виконаних

Т а б л и ц я 1. Рівень загальних когнітивних здібностей кваліфрікованих бадмінтоністів $(\mathrm{n}=34)$

\begin{tabular}{|c|c|c|c|c|c|}
\hline \multirow{2}{*}{ Тест } & \multirow{2}{*}{ Показник } & \multicolumn{4}{|c|}{ Значення } \\
\hline & & медіана & $\begin{array}{c}\text { нижній } \\
\text { квартиль }\end{array}$ & $\begin{array}{c}\text { верхній } \\
\text { квартиль }\end{array}$ & CV, $\%$ \\
\hline \multirow{4}{*}{ 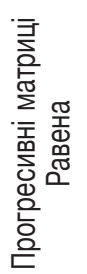 } & $\begin{array}{l}\text { Продуктивність, кількість } \\
\text { сигналів }\end{array}$ & 9,00 & 6,00 & 10,00 & 25,95 \\
\hline & Швидкість, сигнал/хв ${ }^{-1}$ & 4,12 & 3,43 & 6,07 & 58,57 \\
\hline & Точність, ум. од. & 0,75 & 0,50 & 0,83 & 26,77 \\
\hline & Ефективність, \% & 53,57 & 21,42 & 67,46 & 52,79 \\
\hline
\end{tabular}

завдань за весь час виконання тесту (сумарне число правильних відповідей);

- швидкість - кількість сигналів, переглянутих за одиницю часу, сигнал $\cdot \mathrm{c}^{-1}$;

- точність - відношення сумарного числа правильних відповідей до загальної кількості переглянутих (пред'явлених) пунктів, вимірюється в ум. од.;

- ефективність - інтегральний показник, розраховується як відношення правильно виконаних завдань до загальної кількості завдань у тесті, скориговане на ймовірність випадкового вгадування, виражається у \%.

Характер та результативність когнітивних здібностей оцінюють за кількісними (продуктивність та швидкість виконаних завдань) та якісними оцінками (точність та ефективність виконаних завдань).

у таблиці 1 представлено результати тестування загальних когнітивних здібностей бадмінтоністів. За основним інформативним показником (продуктивністю) спортсмени мають середній рівень (Ме = 9), розкид значень коливається в межах від середнього до високого, група неоднорідна (CV = 25,95 \%).

Швидкість виконання тесту у вибірці відповідає середньому рівню $\left(\mathrm{Me}=4,12\right.$ сигнал $\left.\cdot \mathrm{xB}^{-1}\right)$, розкид показників коливається межах від середнього до високого рівня, група неоднорідна (CV = 25,95 \%).

Якість (точність) виконання тесту знаходиться на середньому рів- 
Т а б л и ц я 2. Рівень загальних когнітивних здібностей кваліфікованих бадмінтоністів з урахуванням статевого диморфізму

\begin{tabular}{|c|c|c|c|}
\hline \multirow{3}{*}{ Тест } & \multirow{3}{*}{ Показник } & \multicolumn{2}{|c|}{ Значення показників } \\
\hline & & чоловіки (n = 12) & жінки (n = 22) \\
\hline & & $\begin{array}{c}\text { медіана, нижній квартиль, } \\
\text { верхній квартиль }\end{array}$ & $\begin{array}{c}\text { медіана, нижній квартиль, } \\
\text { верхній квартиль }\end{array}$ \\
\hline \multirow{4}{*}{ 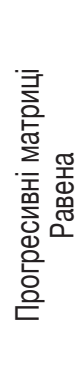 } & $\begin{array}{l}\text { Продуктивність, } \\
\text { сигналів }\end{array}$ & $\begin{array}{c}8,00 \\
(6,00 ; 9,00)\end{array}$ & $\begin{array}{c}10,00 * \\
(7,00 ; 10,00)\end{array}$ \\
\hline & $\begin{array}{l}\text { Швидкість, } \\
\text { сигнал } \cdot \mathrm{XB}^{-1}\end{array}$ & $\begin{array}{c}3,95 \\
(3,13 ; 5,35)\end{array}$ & $\begin{array}{c}4,35 \\
(3,47 ; 6,53)\end{array}$ \\
\hline & Точність, ум. од. & $\begin{array}{c}0,67 \\
(0,50 ; 0,75)\end{array}$ & $\begin{array}{c}0,83^{*} \\
(0,58 ; 0,91)\end{array}$ \\
\hline & Ефективність, \% & $\begin{array}{c}42,06 \\
(21,42 ; 53,57)\end{array}$ & $\begin{array}{c}67,46^{*} \\
(30,55 ; 82,93)\end{array}$ \\
\hline
\end{tabular}

Примітка. ${ }^{*}$ - відмінність статистично достовірна відносно чоловіків на рівні $p<0,05$

ні $(\mathrm{Me}=0,75)$, розкид значень коливається в межах від низького до середнього, група неоднорідна $(\mathrm{CV}=26,77 \%)$.

За показником ефективності бадмінтоністи мають рівень, нижчий за середній (Me = 53,57 \%), розкид значень знаходяться між низьким та середнім рівнями, група неоднорідна.

Якщо порівнювати загальні когнітивні здібності чоловіків та жінок, які грають у бадмінтон на високому рівні (табл. 2), то аналіз тесту «Прогресивні матриці Равена» показав, що жінки мають достовірно кращі значення за основним інформативним показником продуктивності (Ме ч = 8 сигналів; Ме ж = 10 сигналів), при кращих показниках розкиду (нижній та верхній квартилі).

Швидкість виконання тесту у чоловіків та жінок знаходиться на середньому рівні та не має статистично достовірної різниці, хоча тенденція до кращих результатів у жінок зберігається як за медіаною, так і за нижнім і верхнім квартилями.

Аналіз ефективності когнітивних здібностей свідчить про те, що жінки мають достовірно кращі показники, ніж чоловіки як за медіаною, так і за розкидом значень.

3 таблиці 2 бачимо, що за якістю (точністю) виконання тестування когнітивних здібностей достовір- но кращі значення мають жінки як за медіаною, так і за розкидом показників.

Узагальнюючи результати дослідження когнітивних характеристик бадмінтоністів, можна зробити висновок, що спортсмени, які грають у бадмінтон на високому рівні, мають середній рівень загальних когнітивних здібностей, але жінки демонструють достовірні відмінності за швидкісними і якісними показниками когнітивних тестів.

Висновки. За результатами наукових досліджень когнітивних здібностей кваліфікованих бадмінтоністів було виявлено, що за загальними когнітивними здібностями вони мають середній рівень продуктивності, швидкості та якості (точності) виконання тесту «Просунуті прогресивні матриці Равена». За показником ефективності бадмінтоністи мають рівень, нижчий за середній. Жінки демонструють достовірні відмінності за швидкісними і якісними показниками когнітивних тестів.

Перспективи подальших досліджень полягають у визначенні кореляційних зв'язків між когнітивними характеристиками та когнітивнодіяльнісними стилями кваліфікованих бадмінтоністів.

Конфлікт інтересів. Автори заявляють, що відсутній будь-який конфлікт інтересів.

\section{ЛITEPATУРА}

1. Помыткин ВП. Книга тренера по бадминтону. Теория и практика. Ульяновск: ОАО «Первая образцовая тип.», филиал «Ульяновский дом печати». 2012. 344 с.

2. Равен ДжК, Курт ДжХ. Равен Дж. Руководство к прогрессивным матрицам Равена и словарным шкалам. Раздел 4. Продвинутые прогрессивные матрицы. Москва: МГУ, 2012. $132 \mathrm{c}$.

3. Akhtarieva RF, Zhestkova YK, Shapirova $R R$, Psychophysiological measurements in badminton. Teoriya i Praktika Fizicheskoy Kultury. 2018;3:21-23.

4. Cabello D, Padial P, Lees A, \& Rivas F. Temporal and Physiological Characteristics of Elite Womens and Mens Singles Badminton. International Journal of Applied sports sciences (IJASS) 2004;16(2):1-12.

5. lermakov S, Podrigalo L, Romanenko V Tropin Y, Boychenko N, Rovnaya 0, Kamaev 0. Psycho-physiological features of sportsmen in impact and throwing martial arts. Journal of Physical Education and Sport. 2016;16(2):433-439. doi: 10.7752/jpes.2016.02067.

6. Korobeynikov G, Potop V, Ion M, Korobeynikova L, Borisova O, Tishchenko V, Smoliar I. Psychophysiological state of female handball players with different game roles. Journal of Physical Education and Sport. 2019;19(3):1698-1702. (in English).

7. Korobeynikov G, Cynarski WJ, Mytskan B Dutchak M, Korobeynikova L, Nikonorov D - \& Korobeinikova I. The psychophysiological state of athletes with different levels of aggression. Ido Movement for Culture. Journal of Martial Arts Anthropology. 2019;19(1S):62-66.

8. Kozina Z, lermakov S, Crełu M., Kadutskaya L \& Sobyanin F. Physiological and subjective indicators of reaction to physical load of female basketball players with different game roles. Journal of Physical Education and Sport. 2017;17(1):378-382.

9. Lyzohub V, Chernenko N, Palabiyik A. Kozhemyako T, Bezkopilna S. Age peculiarities of interaction of motor and cognitive brain systems while processing information of different modality and complexity. Regulatory Mechanisms in Biosystems. 2019;(103):288-294. doi 10.15421/021944.

\section{LITERATURE}

1. Pomytkin VP. Coach guide in badminton. Theory and practice. Ulyanovsk: OAO «Pervya obraztsovaya tip.», filial «Ulyanovsk dom pechati». 2012. 344 p.

2. Raven JK, Kurt JH. Raven J. Guide to Raven's progressive matrices and word scales. Moscow: MGU, 2012. 132 p.

3. Akhtarieva RF, Zhestkova YK, Shapirova RR, Psychophysiological measurements in badminton. Teoriya i Praktika Fizicheskoy Kultury. 2018;3:21-23.

4. Cabello D, Padial P, Lees A, \& Rivas F. Temporal and Physiological Characteristics of Elite Womens and Mens Singles Badminton. International Journal of Applied sports sciences (IJASS). 2004;16(2):1-12.

5. lermakov S, Podrigalo L, Romanenko V, Tropin Y, Boychenko N, Rovnaya 0, Kamaev 0. Psycho-physiological features of sportsmen in 


\section{ІНФОРМАЦІЯ ПРО АВТОРІВ}

Сюй Саньцянь https//orsid.org/0000-0002-1426-1813, k.george.65.w@gmail.com

Коробейніков Георгій Валерійович https://orcid.org/0000-0002-1097-4787, k.george.65.w@ gmail.com

Коробейнікова Леся Григорівна https://orcid.org/0000-0001-8648-316X, korlesia.66@gmail. com

Національний університет фізичного виховання і спорту України 03150, Київ, вул. Фізкультури, 1

Міщук Діана Миколаївна https//orsid.org/0000-0001-5920-9421, diana.mischuk9@gmail.com Національний технічний університет України «КПІ імені Ігоря Сікорського» 03056, Київ, вул. Верхньоключова 26/1,

\section{INFORMATION ABOUT THE AUTHORS}

Xu Sanqian https//orsid.org/0000-0002-1426-1813, k.george.65.w@gmail.com

Korobeynikov George https://orcid.org/0000-0002-1097-4787, k.george.65.w@gmail.com

Korobeynikova Lesia https://orcid.org/0000-0001-8648-316X, korlesia.66@gmail.com

National University of Ukraine on Physical Education and Sport

03150, Kyiv, Fizkul'tury str., 1

Mishchuk Diana https//orsid.org/0000-0001-5920-9421, diana.mischuk9@gmail.com Igor Sikorsky National Technical University of Ukraine 03056, Kyiv, Verkhnoklyuchova str., 26/1 impact and throwing martial arts. Journal of Physical Education and Sport. 2016;16(2):433-439. doi: 10.7752/jpes.2016.02067.

6. Korobeynikov G, Potop V, Ion M, Korobeynikova L, Borisova 0 , Tishchenko V, Smoliar I. Psychophysiological state of female handball players with different game roles. Journal of Physical Education and Sport. 2019;19(3):1698-1702. (in English).

7. Korobeynikov G, Cynarski WJ, Mytskan B, Dutchak M, Korobeynikova L, Nikonorov D - \& Korobeinikova I. The psychophysiological state of athletes with different levels of aggression. Ido Movement for Culture. Journal of Martial Arts Anthropology. 2019;19(1S):62-66.

8. Kozina Z, lermakov S, Crełu M., Kadutskaya L \& Sobyanin F. Physiological and subjective indicators of reaction to physical load of female basketball players with different game roles. Journal of Physical Education and Sport. 2017;17(1):378-382.

9. Lyzohub V, Chernenko N, Palabiyik A. Kozhemyako T, Bezkopilna S. Age peculiarities of interaction of motor and cognitive brain systems while processing information of different modality and complexity. Regulatory Mechanisms in Biosystems. 2019;(103):288-294. doi: $10.15421 / 021944$. 